\title{
The Influence of Shift on Machined Surface Microgeometry and Its Use
}

Karol Vasilko

Faculty of Manufacturing Technologies, Technical University of Košice, Bayerova 1, 08001 Prešov, SR, karol.vasilko@tuke.sk

Beside cutting speed, shift is another important parameter of machining. Its considerable influence is shown mainly in the workpiece machined surface microgeometry. In practice, mainly its combination with the radius of cutting tool tip rounding is used. Options to further increase machining productivity and machined surface quality are hidden in this approach. The paper presents variations of the design of productive cutting tools for lathe work and milling on the base of the use of the laws of the relationship among the highest reached uneveness of machined surface, tool tip radius and shift.

Keywords: machining, cutting speed, surface roughness

\section{References}

[1] JERSÁK, J. et al.: Surface integrity of hardened bearing steel after milling. Manufacturing Technology, Vol. 10, december 2010, pp. 80-87. ISSN 1213-2489.

[2] KROLCZYK, G., LEGUTKO, S.: The Machinability of Duplex Stainless Steel - Solutions in Practice. Manufacturing Technology, December 2013, Vol, 13, No.4,ISSN 1213-2489

[3] KUNDRÁK, J.: Alternative machining procedures of hardened steels. Manufacturing Technology, 2011, vol XI, pp. 32-39, ISSN 1213-2489

[4] LEGUTKO, S., KROLCZYK, G., KROLCZYK, J.: Quality Evaluation of Surface Layer In Highly Accurate Manufacturing. Manufacturing Technology, March 2014, Vol 14, No.1

[5] Patent SR .Výkonná čelná fréza. č. 287347. Pôvodca: Karol Vasilko , 7.7.2010.

[6] MAKEDONSKI, A.: Unconvential machining method for enhancing the durability of tools and strength of the specimends bonden. Manufacturing Technology, 11/2011, pp. 49-55

[7] STANČEKOVA, D., KURNAVA, T., ŠAJGALIK, M., NAPRSTKOVÁ, N., STRUHARNANSKA, J., ŠČOTKA, P.: Identification of machinability of ceramic materials by turning. Manufacturing Technology, Vol. 14, No. 1, 2014. ISSN 1213-2489

[8] STEPHENSON, D. A., AGAPIOU, J. S.: Metal Cutting Theory and Practice. New York: Taylor \& Francis, 2006, pp. 846, ISBN 0-8247-5888-9

[9] VASILKO, K., MACUROVÁ, A.: Two local extremes of cutting speed. Manufacturing Technology, December 2012, Vol. 12, No. 13, pp. 75-79, ISSN 1213-2489

[10]VASILKO, K., MÁDL, J.: Teorie obrábění. UJEP: Ústí nad Labem, 2012, 526 s., ISSN 978-80-7814-460-8 